\title{
PHYSICAL AND CHEMICAL CHARACTERIZATION OF FRUITS AND DNA CONTENT IN GENOTYPES OF ACEROLA TREE
}

Thatiane Padilha Menezes ${ }^{1}$, José Carlos Moraes Rufini ${ }^{2}$, Leila Aparecida Salles Pio ${ }^{1}$, Deniete Soares Magalhães ${ }^{2}$, Caio Peixoto Chain ${ }^{1}$ ${ }^{1}$ Universidade Federal de Lavras. E-mail: thatiagro@yahoo.com.br; leilapio.ufla@gmail.com; caiopeixotochain@gmail.com
${ }^{2}$ Universidade Federal de São João Del Rei. E-mail: rufini@ufsj.edu.br; denieteagro@yahoo.com.br

\begin{abstract}
The present study investigated agronomic characteristics of nine genotypes of acerola tree, as well as determined the DNA content of these plants. Sixty fruits from each genotype were harvested at physiological maturity and evaluated in relation to physical and physical-chemical characteristics. The data were submitted to descriptive and multivariate analyses. The characteristics of genotypes were clustered according to the dissimilarity, using the Hierarchical Method of Nearest Neighbor and the Tocher Optimization Method. The results revealed differences between the genotypes, and separated them into four groups. The analysis of DNA content was performed by the genotypes flow cytometry. Three samples of each genotype along with the internal reference standard (pea) were prepared and then 10.000 cores on a logarithmic scale were analyzed. The genotypes tested, in relation to the DNA content, can be separated into two groups. Finally, it was concluded that there is little correlation between citometry and characterization of acerola fruits.
\end{abstract}

Keywords: Quality of fruit, genetic variability, flow cytometry, fruit breeding

\section{CARACTERIZAÇÃO FÍSICO-QUÍMICA DE FRUTOS E CONTEÚDO DE DNA EM GENÓTIPOS DE ACEROLEIRAS}

\section{RESUMO}

Este trabalho objetivou estudar características agronômicas de nove genótipos de aceroleiras, assim como determinar o conteúdo de DNA das plantas. Para isso foram colhidos 60 frutos de cada genótipo em estágio de maturação fisiológica e avaliados em relação às características físicas e físico-

químicas. Os dados obtidos foram submetidos às análises descritiva e multivariada. Foi realizado o 336 
agrupamento das características dos genótipos de acordo com a dissimilaridade, empregando-se o método Hierárquico do Vizinho Mais Próximo e o Método de Otimização de Tocher. Os resultados revelaram divergências entre os acessos, separando-os em quatro grupos. Para o estudo do conteúdo de DNA foi realizada a análise dos genótipos através da citometria de fluxo. Foram preparadas três amostras de cada genótipo juntamente com o padrão interno de referência (ervilha), sendo analisados 10 mil núcleos em escala logarítmica. Os genótipos estudados, em relação ao conteúdo de DNA, podem ser separados em dois grupos.

Palavras-chave: Qualidade de fruto, variabilidade genética, citometria de fluxo, melhoramento de frutas

\section{INTRODUCTION}

Originated from the Antilles, North and South America, the acerola tree (Malpighiae marginata D.C.) has been adapting to different localities and cultivated mainly in Brazil, Puerto Rico, Cuba, and the United States. Due to its potential as a natural consumption and its capacity for industrial use, this fruit has attracted the interest of fruit growers and became of economic importance in several regions of Brazil (MAIA et al., 2007).

However, the absence of definite varieties of acerolas trees in Brazil and planting seedlings from seed are the main factors that lead to the great disparity in the annual production of fruits per plant. This fact poses serious difficulties for producers, causing losses in productivity and fruit quality (SALLA et al., 2002). Researches have been carried out with the purpose of selecting plants that produce fruits with characteristics of interest for plant breeding and for the market of fresh and industrialized fruits, in an attempt to solve these problems.

In general, breeding programs are performed based on the evaluation of agronomic characteristics of the plant and fruit quality (NETO et al., 2012). On the other hand, flow cytometry is an important tool that can also be used to characterize individuals. In this technique, the particles (cell nuclei) are analyzed individually at high speed, and large populations can have the DNA content measured in a short period of time (SHAPIRO, 2004).

Therefore, the present work aimed at studying the variability of genotypes of acerola tree through the physical-chemical characterization of the fruits, as well as to determine the DNA content using flow cytometry and to verify possible correlation between the two analyses. 


\section{MATERIAL AND METHODS}

For the research, physiologically mature fruits of nine genotypes of acerola tree with 15 years old were harvested manually at random in a commercial orchard made from seeds located in Jequitibá, in the state of Minas Gerais, Brazil, whose area presents approximately 800 plants. The place is at $19^{\circ} 15^{\prime}$ south latitude and $44^{\circ} 15^{\prime}$ west longitude, with an altitude of $644 \mathrm{~m}$. The climate of the region is classified as Tropical Humid, with an average annual temperature of $20.2{ }^{\circ} \mathrm{C}$ and an average annual rainfall of $1328.7 \mathrm{~mm}$ (IGA, 2012).

Sixty fruits per plant were harvested in three production seasons (2012, 2013 and 2014). After each collection, the acerolas were packed in styrofoam box and taken into the Plant Production Laboratory of the Federal University of São João Del Rei (Campus Sete Lagoas, MG), where the following physico-chemical analyses were carried out:

a) Fresh fruit mass (PF): obtained by means of a digital scale and expressed in grams.

b) Transverse (DT) and longitudinal (DL) diameter: evaluated through a digital caliper and results expressed in centimeter $(\mathrm{cm})$, in addition to DL / DT.

c) Seed mass (DM) and pulp mass (MP): obtained by manual separation of fruit pulp and seed, weighed separately in digital balance, with results in grams.

d) Fruit humidity (U): Carried out in a forced air circulation oven, at $70^{\circ} \mathrm{C}$, until constant weight.

e) Yield fruit, expressed in \%, obtained by weighing the peel, seed and pulp.

f) Concentration of soluble solids (SS) performed in a digital refractometer with automatic temperature compensation, the results being expressed as a percentage (AOAC, 2012).

g) Titratable acidity (TA) was determined by weighing $1 \mathrm{~g}$ of fruit pulp in a digital analytical balance and then adding $20 \mathrm{~mL}$ of distilled water. The material was crushed in polytron, followed by filtration in organza. The solution was added three samples of the phenolphthalein indicator, and the titrations were carried out with 0.1N NaOH solution under agitation (INSTITUTO ADOLFO LUTZ, 1985). Values were expressed as percent of malic acid.

h) SS / TA ratio: obtained by the soluble solids / titratable acidity quotient.

i) The $\mathrm{pH}$ determined by means of digital $\mathrm{Ph}$ metro, with values ranging from 0 - 14 (AOAC, 2012).

The data were subjected to descriptive analysis, evaluating the mean, standard deviation and coefficient of variation. The genotypes were clustered together using the Hierarchical Nearest Neighbor method and the Tocher Optimization Method through the Genes Software (CRUZ, 2006). 


\section{PHYSICAL AND CHEMICAL CHARACTERIZATION OF FRUITS AND DNA CONTENT IN GENOTYPES OF ACEROLA TREE}

After the agronomic characterization of the genotypes of acerola tree, flow cytometric analyses were performed to determine the DNA content. For this, young leaves from each plant were collected. Subsequently, the materials were packed with cotton swabs moistened in plastic bags and transported in a styrofoam box to the Federal University of Lavras, in the Department of Agriculture, Plant Tissue Culture Laboratory, where they were evaluated.

For the determination of DNA content, about $50 \mathrm{mg}$ of young leaf together with Pisum sativa (internal reference standard) (DOLEZELet al., 1989) were ground in a Petri dish containing $1 \mathrm{ml}$ of icecold Marie buffer for the release of the nucleus.

The suspension of the nucleus was aspirated through two layers of gauze, using a Pauster pipette and filtered through a $50 \mu \mathrm{m}$ mesh. The nucleus was stained by the addition of $15 \mu l$ of propidium iodide. Immediately after preparation, the samples were analyzed in triplicate (protocol adapted from Galbraith et al., 1983).

For each sample 10.000 nucleus were analyzed using a logarithmic scale. The analysis was performed on the cycometer Facscalibur (Becton Dickinson). The histograms were obtained by the Cell Quest software and analyzed statistically in WinMDI 2.8 software.

The coefficients of variation (CV) and DNA contents (pg) obtained were submitted to analysis of variance by the Test $F$ and the means were grouped by the Scott-Knott test $(p \leq 0.05)$.

\section{RESULTS AND DISCUSSION}

The physical-chemical characterization of acerola fruits is shown in Table 1, where the existence of variability among the genotypes is verified for most of the studied parameters.

The variation for the longitudinal and transverse diameters was 17.51 to $21.25 \mathrm{~mm}$ and 19.33 to $24.67 \mathrm{~mm}$, respectively. The coefficient of variation was the highest for the transversal diameter (8.164\%). The DL / DT relationship ranged from 0.83 to 0.93 with a coefficient of variation of $3.843 \%$. This characteristic refers to the shape of the fruit, and the results are consistent with those obtained by Brunini et al. (2004), 0.86 to 1.24. According to this author, the acerola is a subglobous drupe.

The range of variation for fruit mass was from 3.46 to $7.26 \mathrm{~g}$, with a coefficient of variation of 20.74\%. Genotypes 3, 4, 8, and 9 presented values above the mean (5.52 g), with genotype 8 being highlighted. These values are lower than those found by Brunini et al. (2004) (6.92 to $9.60 \mathrm{~g}$ ) of acerola fruit from Guariba, in the state of São Paulo, Brazil, Pioneiros and Guará. This difference is likely to be 
related to climatic divergences between growing sites. It should be noted that larger fruits are more attractive to the fresh market.

Table 1. Mean values for physical-chemical characteristics of fruits of nine genotypes of acerola (Malphigia emarginata D.C.) in three production seasons.

\begin{tabular}{l|l|l|l|l|l|l|l|l|l|l|l|l}
\hline Genotype & pH & SST & AT & $\begin{array}{l}\text { SS/ } \\
\text { UT }\end{array}$ & & MF & MS & MP & $\begin{array}{l}\text { Yield } \\
\text { fruit }\end{array}$ & DL & DT & $\begin{array}{l}\text { DL/ } \\
\text { DT }\end{array}$ \\
\hline 1 & 3.47 & 6.51 & 1.57 & 4.30 & 92.45 & 3.46 & 0.64 & 2.82 & 81.28 & 17.51 & 19.33 & 0.91 \\
2 & 3.86 & 5.93 & 0.85 & 7.09 & 92.64 & 5.47 & 1.23 & 4.24 & 77.39 & 19.90 & 22.76 & 0.88 \\
3 & 3.96 & 7.04 & 1.13 & 6.21 & 90.67 & 6.51 & 1.55 & 4.96 & 75.90 & 20.76 & 24.30 & 0.85 \\
4 & 4.63 & 5.91 & 1.02 & 5.97 & 91.44 & 6.38 & 1.22 & 5.16 & 81.22 & 20.80 & 24.28 & 0.86 \\
5 & 4.28 & 6.69 & 1.34 & 4.98 & 92.24 & 4.97 & 1.04 & 3.93 & 78.27 & 18.51 & 22.37 & 0.83 \\
6 & 4.13 & 8.04 & 2.62 & 3.48 & 91.77 & 4.43 & 0.85 & 3.58 & 78.13 & 18.26 & 20.07 & 0.92 \\
7 & 4.17 & 6.50 & 0.95 & 7.22 & 90.41 & 5.63 & 1.35 & 4.28 & 75.91 & 19.66 & 22.76 & 0.86 \\
8 & 3.36 & 7.78 & 1.73 & 4.80 & 91.83 & 7.26 & 1.86 & 5.40 & 74.08 & 21.25 & 24.67 & 0.86 \\
9 & 3.85 & 7.18 & 1.50 & 5.03 & 90.07 & 5.53 & 1.41 & 4.12 & 74.06 & 21.09 & 22.71 & 0.93 \\
\hline Mean & 3.97 & 6.84 & 1.41 & 5.45 & 91.61 & 5.52 & 1.24 & 4.28 & 77.36 & 19.75 & 22.58 & 0.88 \\
Minimum & 3.36 & 5.91 & 0.85 & 3.48 & 90.07 & 3.46 & 0.64 & 2.82 & 74.06 & 17.51 & 19.33 & 0.83 \\
Maximum & 4.63 & 8.04 & 2.62 & 7.22 & 92.64 & 7.26 & 1.86 & 5.40 & 81.28 & 21.25 & 24.67 & 0.93 \\
D.P. & 0.39 & 0.74 & 0.54 & 1.26 & 0.98 & 1.14 & 0.37 & 0.81 & 2.68 & 1.37 & 1.84 & 0,03 \\
C.V(\%) & 9.91 & 10.8 & 38.52 & 23.08 & 1.06 & 20.74 & 36.58 & 18.94 & 3.46 & 6.93 & 8.16 & 3.84 \\
\hline
\end{tabular}

$\mathrm{pH}=$ Hydrogen ionic potential; SST $=$ Soluble solids $\left({ }^{\circ}\right.$ Brix $) ; \mathrm{AT}=$ Titratable acidity $(\%$ malic acid $) ; \mathrm{SS} / \mathrm{AT}=$ Soluble solids / titratable acidity ratio; $\mathrm{U}=$ moisture of the fruit; $\mathrm{MF}=$ fresh fruit mass $(\mathrm{g}) ; \mathrm{MS}=$ seed mass of the fruit $(\mathrm{g}) ; \mathrm{MP}=$ Mass of pulp (g); Yield fruit = Yield (\%); DL = Longitudinal diameter $(\mathrm{mm}) ; \mathrm{DT}=$ Trans verse diameter $(\mathrm{mm}) ; \mathrm{DL} / \mathrm{DT}=$ Cross-sectional diameter ratio / longitudinal diameter; D.P = Standard Deviation; C.V = Coefficient of Variation (\%).

The range of variation for pulp mass was 2.82 to $5.40 \mathrm{~g}$, with a mean of $4.28 \mathrm{~g}$. It was verified that the average percentage of pulp in relation to the fruit is $77.53 \%$. For this characteristic, genotypes 3 , 4 and 8 stand out.

The yield of the fruit presented low C.V. (3.469\%), ranging from 74.06 to $81.08 \%$, similar to that found by Carpentieri-Pípolo et al. (2002) for three acerola cultivars. This characteristic is important in the quality of the acerola for industrial processing (MACIEL et al., 2010). 


\section{PHYSICAL AND CHEMICAL CHARACTERIZATION OF FRUITS AND DNA CONTENT IN GENOTYPES OF ACEROLA TREE}

The fruit's seed mass varied from 0.64 to $1.86 \mathrm{~g}$, showing high variability, confirmed by the coefficient of variation $(36.58 \%)$.

Another characteristic with wide variation was titratable acidity (0.75 to $2.62 \%)$, with a mean of $1.41 \%$. Genotypes with titratable acidity values above $1.00 \%$ do not require addition of acid for the pulp conservation, a method used to hinder the development of microorganisms, which are interesting for industrial use (LIMA et al., 2002; PINTO et al., 2003). In this study, all genotypes presented titratable acidity above $1 \%$, except for 2 and 7 .

According to Maciel et al. (2010), the state of conservation of fruits can be evaluated by the acidity, and together with the soluble solids contents, are important characteristics in relation to flavor.

The soluble solids contents and the SS / AT ratio had a range of variation of 5.91 to $7.78^{\circ}$ Brix and 3.48 to 7.09, respectively. For these parameters, genotypes 3, 6, 8, and 9 for soluble solids contents and genotypes 2, 3, 4, and 7 for SS / AT stand out. Researches reported soluble solids content in ripe acerolas from 5.7 to $6.5^{\circ}$ Brix (BRUNINI et al., 2004); 7.47 to $8.73{ }^{\circ}$ Brix (MUSSER et al., 2004). Values above $8 \%$, according to Lopes \& Paiva (2002), are indicated for industry. In this study, only genotype 6 presented a value above $8 \%$.

The relationship between SS / AT determines the flavor of the fruits, thus, the higher the ratio, the sweeter the fruits (MACIEL et al., 2010).

The $\mathrm{pH}$ of the fruits presented an average of 3.97, ranging from 3.36 to 4.63, being genotypes 4, 5, 6, and 7 above the mean value. These results are above those reported by Maciel et al. (2010), studying 18 genotypes of acerola.

Among the studied variables, the humidity of the fruits was the one with the lowest variation, 90.07 to $92.64 \%$, and also the lowest coefficient of variation $1.06 \%$.

A dendrogram of the genetic dissimilarity of the physical and chemical characteristics of the genotypes was elaborated (Figure 1), where it was possible to verify the formation of four distinct groups, considering the cut-off point at a distance of 0.31 , that is, approximately $75 \%$ of similarity.

It can be seen from Figure 1 that group 1 is formed by genotype 6, group 2 by genotype 1, group 3 by genotype 9 and group 4 by others, being the most numerous, accounting for $66.66 \%$ of the evaluated genotypes. 


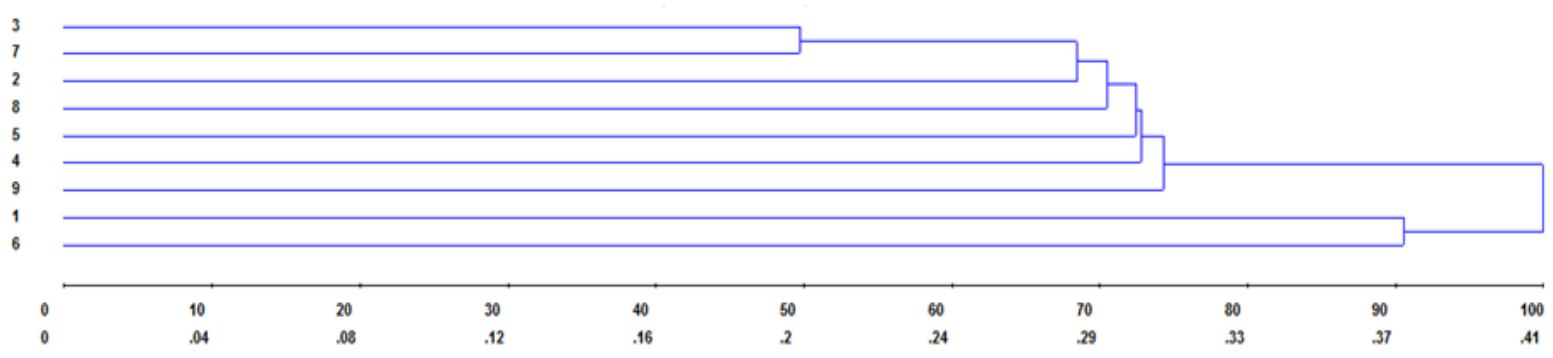

Figure 1. Dendrogram of genetic dissimilarity among nine acerola genotypes by means of the Nearest Neighbor Cluster method.

According to Cruz \& Carneiro (2003), within each group the accesses have similar characteristics and between the groups different characteristics are verified.

By clustering analysis using Tocher optimization (Table 2) was also observed the formation of four groups. By this method it was possible to verify that genotypes 3, 7, 2, 5, and 4 are in the same group. Genotypes 1 and 6 in a second group and genotypes 9 and 8 were isolated.

Table 2. Formation of groups of acerola genotypes by the Tocher clustering method based on Average Euclidean Distance.

\begin{tabular}{|c|c|}
\hline Group & Genotype \\
\hline $\mathrm{I}$ & $\begin{array}{llll}37 & 2 & 5 & 4\end{array}$ \\
\hline II & 16 \\
\hline III & 9 \\
\hline IV & 8 \\
\hline
\end{tabular}

The two methods showed similarities in the clusters, however, they were not identical, because by the Tocher method genotypes 1 and 6 are in the same group and the genotype 8 is isolated.

According to Dias et al. (2011) genetic variability among genotypes, once confirmed, can be fixed by vegetative propagation methods, and can be used for conservation in active germplasm banks (BAG) and in breeding programs.

By flow cytometric analysis it was possible to verify the amount of nuclear DNA of the genotypes. Table 3 shows differences in the DNA index between the materials, presenting genotypes 1, 3, 4, 5, and 
6 similar DNA content. The other genotypes have similar DNA index. Therefore, in relation to the amount of cellular DNA, the plants of this study are distinguished in two groups.

Table 3. DNA Index (ID) and Coefficient of Variation (CV) of acerola genotypes.

\begin{tabular}{lll}
\hline Acerola tree genotype & ID Peak 1 & CV Peak 1 \\
\hline 1 & $2,53 \mathrm{a}$ & 0,55 \\
2 & $2,34 \mathrm{~b}$ & 0,59 \\
3 & $2,47 \mathrm{a}$ & 0,47 \\
4 & $2,57 \mathrm{a}$ & 0,60 \\
5 & $2,56 \mathrm{a}$ & 0,76 \\
6 & $2,54 \mathrm{a}$ & 0,64 \\
7 & $2,37 \mathrm{~b}$ & 0,64 \\
8 & $2,36 \mathrm{~b}$ & 0,47 \\
9 & $2,42 \mathrm{~b}$ & 0,56 \\
\hline C.V. & 4,06 & 18,68
\end{tabular}

Averages followed by the same vertical letter belong to the same group and do not differ from one another by the Scott-Knott test at the $5 \%$ probability level.

The histograms CVs were very low, proving the reliability of the analysis. According to Galbraith et al. (2001), the reliability of flow cytometric analysis is related to $\mathrm{CV}$, the two parameters being inversely proportional. According to Guimarães et al. (2009), CV above 5\% is not accepted in the literature. In this study, a coefficient of variation was observed below $5 \%$ in all evaluated genotypes (Table 3).

The results of genotype groupings regarding fruit quality characteristics and DNA index had few relationships. It was expected that for the genotypes with the highest DNA content there would be a trend of greater fruit size, fresh fruit and seed mass.

However, this was confirmed only for genotype 8 (Tables 1 and 3), which presents these characteristics and is included in the group of genotypes with the highest amount of DNA. At the same time, genotype 1 has lower DNA content and has smaller fruit and seed size characteristics.

Both genotypes (1 and 8 ) are part of the extremes of these analyzes, but the others are mixed in relation to these characteristics. Possibly the agronomic characters studied in the present work may have been influenced by the environment. 
The "giga effect" is observed through the analysis of morphological and anatomical characteristics in which the organs and cells of the plant increase in volume proportionally to the increase of the amount of DNA (PEREIRA et al., 2012).

In addition, the literature reports that the presence of secondary metabolites may influence the nuclear DNA staining by fluochromes. Probably, compounds derived from the secondary metabolism of the acerola genotypes present on the leaves may have affected the staining of the DNA molecule.

The use of flow cytometry has already been used in several species. Carvalho et al. (2008), in studies with jatropha, determined the size of the genome and the haploid content of DNA. Couto et al. (2013) working with maize applied the cytometry to identify haploids and to correlate the DNA content with the morphological and morphometric characters of the seeds that originated them. Brito et al. (2008) used flow cytometry and microsatellite markers for the genetic characterization of olive trees.

The histograms generated by the flow cytometry are represented by Figure 2. It is possible to verify two peaks representing the G0 / G1 phase of the cell cycle. The first refers to the peak of the sample and the second to the reference standard. Based on the two peaks the DNA content was calculated, as shown in Table 3.

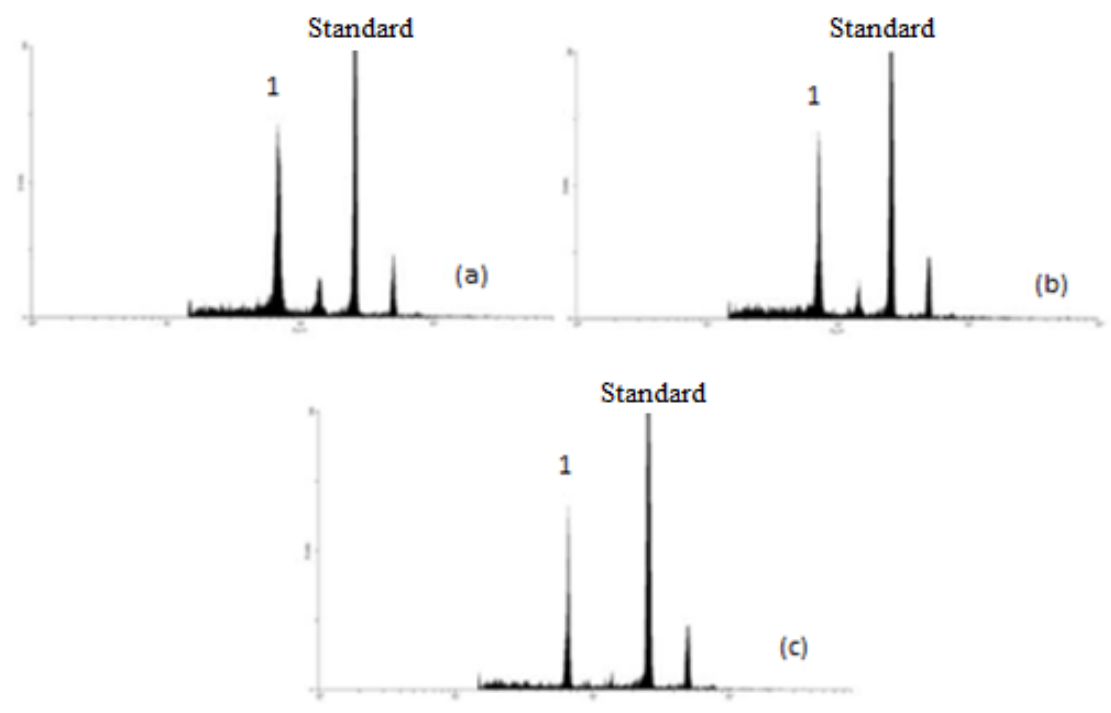

Figure 2. Histograms of flow cytometry of acerola genotypes, together with pea (Pisum sativum L.) used as reference standard. Genotype 1 (a), genotype 3 (b), genotype 8 (c). 


\section{CONCLUSION}

The fruits are classified into four groups in relation to physical-chemical characteristics and flow cytometry in two groups.

There is little correlation between citometry and characterization of acerola fruits.

\section{REFERENCES}

AOAC - Association of Official Analytical Chemestry. 2012. Official methods of analysis.19 th $^{\text {ed. }}$ Gaithersburg, 3000p.

BRUNINI, M. A; MACEDO, N. B.; COELHO, C. V.; SIQUEIRA, G. F. de. 2004. Caracterização física e química de acerolas provenientes de diferentes regiões de cultivo. Revista Brasileira de Fruticultura, Jaboticabal, v. 26, n. 3, p. 486-489.

BRITO, G.; LOUREIRO, J.; LOPES, T.; RODRIGUEZ, E.; SANTOS, C. 2008. Genetic characterization of olive trees from Madeira Archipelago using flow cytometry and microsatellite markers. Genetic resources and crop evolution. v. 55, p. 657-664.

CRUZ, C.D.; CARNEIRO, P.C.S.2003. Modelos biométricos aplicados ao melhoramento genético. Viçosa: UFV, v.2, p. 585.

CARPENTIERI-PÍPOLO, V.; PRETE, C. E. C.; GONZALEZ, G. N.; POPPER, I. O. 2002. Novas cultivares de acerola (Malpighiae marginata DC): UEL 3 - Dominga, UEL 4 - Lígia e UEL 5 Natália. Revista Brasileira de Fruticultura, v. 24, n. 1, p. 124-126.

CRUZ, C.D. 2006. Programa Genes: Biometria. Viçosa: Editora UFV, p. 382

CARVALHO, C. R.; CLARINDO, W. R.; PRAÇA, M.M.; ARAÚJO, F.S.; CARELS, N. 2008. Genome size, base composition and karyotype of Jatrophacurcas L., an important biofuel plant. Plant Science, Oxford, v.174, n.6, p. 613-617.

COUTO, E. G. de. O.; DAVIDE, L. M. C.; BUSTAMANTE, F. de. O.; PINHO, R. G. V.; SILVA, T. N. 2013. Identification of haploid maize by flow cytometry, morphological and molecular markers. Ciência e Agrotecnologia, v. 37, n.1, p. 25-31.

DIAS, A. B.; CARVALHO, M. A. P.; DANTAS, A. C. V. L.; FONSECA, A. J. A. 2011. Variabilidade e caracterização de frutos de pitangueiras em municípios baianos. Revista Brasileira de Fruticultura, Jaboticabal, v. 33, n. 4, p. 1669-1177.

DOLEZEL, J.; BINAROVA, P.; LUCRETTI, S. 1989. Analysis of nuclear DNA content in plant cells by flow cytometry. Biologia Plantarum, v. 31, p. 113-120.

GALBRAITH, D. W.; HARKINS, K.R.; MADDOX, J.M.; AYRES, N.M.; SHARMA, D.P.; FIROOZABADY, E. 1983. Rapid flow cytometric analysis of the cell cycle in intact plant tissues. Science, New York, v. 220, n. 4601, p. 1049-1051.

GALBRAITH, D. W.; LAMBERT, G.M.; MACAS, J.; DOLEZEL, J. 2001. Analysis of nuclear DNA content and ploidy in higher plants. Current Protocols in Citometry, Somerest, v. 7, n.3. p. 7-22.

GUIMARÃES, N. C.C.; TORGA, P.P.; RESENDE, E. C.de.; CHALFUN JUNIOR, A.; PAIVA, E.; PAIVA, L. V. 2009. Identificação de variantes somaclonais em bananeiras 'Prata Anã', utilizando técnicas moleculares e citogenéticas. Ciência e agrotecnologia, Lavras, vol.33, n.2, p. 448-454.

INSTITUTO ADOLFO LUTZ. 1985. Normas Analíticas: método químico e físico para análise de alimentos. 2.ed. São Paulo, SP, v. 1, 371p.

IGA. Instituto de Geociências Aplicadas. 2012. 
LIMA, V. L. A. G. de; MELO, E. de A.; LIMA, D. E. da S. Fenólicos e carotenóides totais em pitanga. 2002. Scientia Agrícola, Piracicaba, v. 59, n.3, p. 447- 450.

LOARCE, Y.; GALLEGO, R.; FERRER, E.1996. A comparative analysis of the genetic relationship between rye cultivars using RFLP and RAPD markers. Euphytica, Wageningen, v. 88, p. 107-115.

MAIA, G. A.; SOUSA, P. H. M.; SANTOS, G. M.; SILVA, D. S.; FERNANDES, A. G.; PRADO, G. M. 2007. Efeito do processamento sobre os componentes do suco de acerola. Ciência e Tecnologia de Alimentos, Campinas, v.27, n.1, p.130-134.

MACIEL, M. I. S.; MELO, E.; LIMA, V.; SOUZA, K. A.; SILVA, W. 2010. Caracterização físicoquímica de frutos de genótipos de aceroleira (Malpighiaemarginata D.C.). Ciência Tecnologia de Alimentos, Campinas, v. 30, n. 4, p. 865-869.

MUSSER, R. S.; LEMOS, M. A.; LIMA, V. L. A. G.; MELO, E. A.; LEDERMAN, I.E.; SANTOS, V. F. Características físico-químicas de acerola do banco ativo de germoplasma em Pernambuco. 2004. Ciência e Tecnologia de Alimentos, Campinas, v. 24, n. 4, p. 556-561.

NETO, J. C.; RABELO, M. C.; BERTINI, C. H. C. de M.; MARQUES, G. V.; MIRANDA, M. R. A. de. 2012. Caracterização agronômica e potencial antioxidante de frutos de clones de aceroleira. Revista Ciência Agronômica, Fortaleza, v. 43, n. 4, p. 713-721.

SALLA, M.F.S.; RUAS, C.F.; RUAS, P. M.; CARPENTIERI-PIPOLO, V. 2002.Uso de marcadores moleculares na análise da variabilidade genética em acerola (Malpighiae marginata D.C.). Revista Brasileira de Fruticultura, Jaboticabal, v. 24, n. 1. p. 15-22.

SHAPIRO, H. M. The evolution of cytometers. 2004. Citometry Part A, New York, v. 58A, N. 1, p. 13-20.

LOPES, R.; PAIVA, J. R. 2002. Aceroleira. In: BRUCKNER, C. H. (Org.). Melhoramento de fruteiras tropicais. Viçosa: UFV, v. 1, p. 63-99.

PEREIRA, R. C.; DAVIDE, L. C.; TECHIO, V. H.; TIMBÓ, A. L.O. 2012. Duplicação cromossômica de gramíneas forrageiras: uma alternativa para programas de melhoramento genético. Ciência Rural, Santa Maria, v. 42, n. 7.p. 1278-1285.

PINTO W. S.; DANTAS, A. C. V. L.; FOnSECA, A. A. O.; LEDO, C. A. S.; JESUS, S. C.; CALAFANGE, P. L. P.; ANDRADE, E. M. 2003. Caracterização física, físico-química e química de frutos de genótipos de cajazeiras. Pesquisa Agropecuária Brasileira, Brasília, v. 38, n. 9, p. 1059-1066. 